\title{
Molecular Characterization of Coat Protein Gene of Horse Gram Yellow Mosaic Virus (HgYMV) from Southern India
}

\author{
G. U. Prema ${ }^{1}$ and K. T. Rangaswamy ${ }^{2}$ \\ ${ }^{1}$ Department of Plant Pathology, College of Agriculture, \\ Vijaypur, UAS, Dharwad- 586 101, India \\ ${ }^{2}$ Department of Plant Pathology, College of Agriculture, \\ UAS, GKVK, Bengaluru- 560 065, India \\ *Corresponding author
}

\section{A B S T R A C T}

\section{Keywords \\ Coat protein gene, Horsegram, Yellow mosaic virus, Whitefly, Begomovirus, Phylogenetic analysis, Sequence comparision}

\section{Article Info}

Accepted: 15 December 2019 Available Online: 20 January 2020
Horse gram leaf samples showing yellow mosaic symptoms gave positive results with HgYMV specific primer pairs (HgYMV-CP-F/HgYMV-CP-R) and yielded amplicons of $\sim 1000$ bp whereas no PCR product was obtained from DNA extracted from healthy samples in PCR. The 1000 bp PCR products were cloned, sequenced, assembled and its length was determined as 885 bp including $111 \mathrm{bp}$ pre-coat protein at 5 ' end and 774 core coat protein. The length of the predicted amino acid sequence was found to be 257 . Phylogenetic tree based on full length coat protein gene sequences of HgYMV with 23 other geminivirus sequences downloaded from NCBI Genbank formed three major clusters of MYMIV, HgYMV and MYMV. The present isolate formed unique cluster with HgYMV group that cause yellow mosaic disease symptoms in horsegram (AJ627904.1) and frenchbean (GU323321.1). Comparison of complete nucleotide sequence of coat protein gene of $\mathrm{HgYMV}$ indicated that coat protein gene of HgYMV-GKVK-Bangalore isolate had maximum homology with HgYMV-Tamil Nadu:HG [AJ627904.1] (99.2\%), followed by HgYMV-Srilanka:FB [GU323321.1] (95.2\%). HgYMV-GKVK-Bangalore isolate had 85.2-86.9 per cent identity and 80.2-81.9 per cent identity with MYMV and MYMIV isolates, respectively. Comparison of predicted amino acid sequence of coat protein gene of $\mathrm{HgYMV}$ revealed that HgYMV-GKVK-Bangalore isolate shared maximum amino acid identity with HgYMV-Tamil Nadu:HG [AJ627904.1] (99.2\%), followed by HgYMV-Srilanka:FB [GU323321.1] (97.2\%). HgYMV-GKVK-Bangalore isolate had 91-92.2 per cent identity and 82.8-84.8 per cent identity with MYMV and MYMIV isolates, respectively. From the above results, it is clear that HgYMV-GKVKBangalore is closely related to HgYMV isolates rather than MYMV and MYMIV.

\section{Introduction}

Horsegram (Macrotyloma uniflorum (Lam.) Verdc.) commonly known as kulthi, is one of the hardiest and drought tolerant crops, grown extensively in peninsular India as poor man's pulse crop. Horsegram is an indigenous plant cultivated in India, other Asian countries and Africa (Jayan and Maya, 2001). Among viral diseases, yellow mosaic virus is one of the major constraints for its cultivation in peninsular India and was first observed in 
southern districs of Karnataka. Horsegram yellow mosaic disease transmitted by white fly, Bemisia tabaci (Gennadius) was prevalent in most parts of South India (Muniyappa and Reddy, 1976; Muniyappa et al., 1975; Williams et al., 1968 and Prema, 2013). The disease incidence ranged from 50 to 100 per cent in both summer and early rainy season crops causing substantial loss in grain yield (Muniyappa et al., 1976). The disease caused yellow discoloration on the leaves that led to irregular, small, greenish yellow mosaic symptoms. Severe infection led to stunted growth of the plant and reduction in the leaf size (Muniyappa et al., 1987; Prema and Rangaswamy, 2017).

Geminiviruses which belong to family Geminiviridae are small plant viruses characterized by a 16-18 nm $\times 30 \mathrm{~nm}$ geminate particles consisting of two joined incomplete icosahedral encapsidating either monopartite or bipartite circular single stranded (ss) DNA genome molecules of about 2700 nucleotides (Harrison et al., 1977; Francki et al., 1980; Harrison and Robinson, 2002). Geminiviruses have been grouped into four genera: Mastrevirus, Curtovirus, Topocuvirus and Begomovirus depending on their vector, host range and genome characteristics (Fauquet and Stanley, 2003; Fauquet et al., 2003).

The viruses causing yellow mosaic diseases of legumes across Southern Asia are identified as four distinct bipartite Begomoviruses namely Mungbean yellow mosaic India virus, Mung bean yellow mosaic virus, Horsegram yellow mosaic virus and Dolichos yellow mosaic virus (Qazi et al., 2007). Most of the yellow mosaic viruses infecting legumes in India were transmitted by the whitefly (B. tabaci Genn.) and not seed or soil borne or sap transmissible, share a very narrow host range within legumes and cause biologically indistinguishable symptoms, making specific identification of the viruses difficult (Nene, 1972).

At present literature is not available at genomic level for HgYMV from Karnataka. The information on phylogenetic relationship with that of other YMV isolates associated with other legumes is not available. So, in this context, the present study was undertaken to characterize the HgYMV by sequencing the core region of the $\mathrm{CP}$ and to establish its genetic relationship with other legume yellow mosaic viruses.

\section{Materials and Methods}

\section{Sample collection}

Horsegram plants showing severe yellow mosaic and mottling symptoms were collected from field at the Zonal Agricultural Research Station, GKVK, University of Agricultural Sciences, Bengaluru, Karnataka (Plate 1). Samples from healthy plants were collected as controls.

\section{Nucleic acid extraction}

The total genomic DNA was extracted from leaf tissues of healthy horsegram plants and YMV infected horsegram plants based on the method of Rouhibakhsh et al. (2008). One hundred and fifty milligrams of fresh YMV infected leaf tissues were ground with liquid nitrogen using sterile pestle and mortar. The whole ground sample was transferred into a fresh 1.5-ml eppendorf tube. $1500 \mu \mathrm{l}$ of prewarmed $\left(65^{\circ} \mathrm{C}\right)$ DNA extraction buffer was added to ground sample taken in $1.5-\mathrm{ml}$ eppendorf tube (added in situ just before DNA extraction). The whole crude sap was incubated for $30 \mathrm{~min}$ at $60^{\circ} \mathrm{C}$ in a water bath with occasional mixing. The supernatant (750 $\mu \mathrm{l})$ was transferred into a fresh $1.5-\mathrm{ml}$ effendorf tube and mixed with equal amount $(750 \mu \mathrm{l})$ of Phenol: chloroform: isoamyl alcohol (25: 24:1) by vertexing. The samples 
were then centrifuged at $13,000 \mathrm{rpm}$ for 10 min using micro centrifuge. The aqueous supernatant was collected in to a fresh $1.5-\mathrm{ml}$ eppendorf tube. The DNA was precipitated by mixing with $300 \mu \mathrm{l}$ of chilled isopropanol + $30 \mu \mathrm{l}$ of $7.5 \mathrm{M}$ Ammonium acetate by inversion. The tubes were centrifuged at $13,000 \mathrm{rpm}$ for $10 \mathrm{~min}$. The resulted pellet was washed with 70 per cent ethanol, dried in a vacuum drier for $10 \mathrm{~min}$ and re-suspended with $40 \mu \mathrm{l}$ of $\mathrm{T}_{10} \mathrm{E}_{0.1}$ buffer $(10 \mathrm{mM}$ Tris- $\mathrm{HCl}$ of $\mathrm{pH} 8.0$ and $0.1 \mathrm{mM}$ EDTA of $\mathrm{pH} 8.0$ ) and stored at $-20^{\circ} \mathrm{C}$. All the DNA extracts were further diluted from 1:10 to 1:40 in single distilled water (SDW) before using for PCR amplifications. The quality and quantity of DNA was assessed at $260 \mathrm{~nm}$ and $280 \mathrm{~nm}$ using UV spectrophotometer.

\section{Primers used, PCR amplification and gel electrophoresis}

In order to determine the nucleotide sequence of coat protein of horsegram yellow mosaic virus, specific primers available in the literature were tried to amplify coat protein region of yellow mosaic viruses of nearly 1000 bp. Primers specific to HgYMV (HgYMV-CP-F- ATG CTT GCA ATT AAG TAC TTG CA/HgYMV-CP-R- TAG GCG TCA TTA GCA TAG GCA) were used for amplification of coat protein gene of horsegram yellow mosaic virus (HgYMV). Primers were designed to get the complete coat protein gene of various yellow mosaic viruses of legume hosts by taking 100 extra nucleotides on both the sides of the gene (Naimuddin and Akram, 2012).

Amplification was performed in Thermocycler (Eppendorf Mastercycler gradient, Hamburg, Germany) programmed for one step of initial denaturation at $94^{\circ}$ for 2 min and 35 cycles of denaturation at $94{ }^{\circ} \mathrm{C}$ for $1 \mathrm{~min}$, annealing at $55{ }^{\circ} \mathrm{C}$ for $2 \mathrm{~min}$ for primers $\mathrm{HgYMV}-\mathrm{CP}-/ \mathrm{HgYMV}-\mathrm{CPR}$ and extension at $72{ }^{\circ} \mathrm{C}$ for $3 \mathrm{~min}$, followed by one step of final extension at $72{ }^{\circ} \mathrm{C}$ for $10 \mathrm{~min}$. PCR was conducted with Dream Taq Master mix (Fermentas) in total reaction mixture volume of $25 \mu \mathrm{l}$ that contained Dream Taq Master mix-13 $\mu \mathrm{l}$; $\mathrm{dH}_{2} \mathrm{O}-4 \mu \mathrm{l}$; forward and reverse primers $(20$ pmole $/ \mu \mathrm{l})-2 \mu \mathrm{l}$ each; DNA template (total nucleic acid-100ng/ $\mu \mathrm{l}$ )$4 \mu \mathrm{l}$ and PCR products were subjected to electrophoresis in $1 \%$ agarose at $50 \mathrm{~V}$ for 45 minutes in Electrophoresis system SCOTLAB (Anachem Ltd.) in Tris-acetateEDTA buffer containing ethidium bromide @ $0.1 \%$. The gel was observed under Gel Documentation System (IMAGO Compact Imaging System, B \& L Systems, Isogen Lifescience, The Netherlands).

\section{Cloning and sequencing of coat protein} gene of YMV infecting horsegram

The PCR products were purified from agarose gel using Qiagen Gel Extraction kit (Qiagen, Hilder, Germany). All amplicons were cloned into the plasmid vector pTZ57R/T using InsTAcloneTM PCR Cloning Kit following the manufacturer's instructions. Transformed colonies were screened and selected on LB agar medium amended with ampicillin, X-gal and IPTG. Isolated plasmids from transformed positive clones were confirmed for the presence of insert using the respective $\mathrm{CP}$ specific primers. The resultant positive clones were fully sequenced in both directions using universal M13 forward and reverse primers. Full length sequence of coat protein of $\mathrm{HgYMV}$ was obtained by aligning of forward and reverse reaction sequences (Sambrook and Russel, 2001).

Phylogenetic analysis, nucleotide and amino acid sequence comparison of coat protein gene of $\mathrm{HgYMV}$ with other geminiviruses

Pairwise and multiple sequence alignment of the full length of coat protein sequence of HgYMV was done using MEGA 5.1 multiple 
alignment tool (Tamura et al., 2007). The phylogenetic neighbor-joining trees and evolutionary analysis were conducted using MEGA 5.1 software package based on coat protein gene sequences of HgYMV with 23 other geminivirus sequences downloaded from NCBI Genbank (Table 1). Robustness of trees was determined by bootstrap sampling of multiple sequence alignment with 1000 replications. Comparison of the nucleotide and amino acid sequences of YMV was analysed by using sequence identity matrix tool of Bio-Edit software (Version 7.9.1).

\section{Results and Discussion}

Molecular cloning and sequencing of coat protein gene of yellow mosaic virus infecting horsegram (HgYMV)

The PCR results indicated that the virus could be detected from 1:20 to 1:40 dilutions. In PCR, horsegram samples showing yellow mosaic symptoms gave positive results with HgYMV specific primer pairs (HgYMV-CPF/HgYMV-CP-R for DNA A) and yielded amplicons of $\sim 1000 \mathrm{bp}$ (Plate 2) which clearly indicated that the yellow mosaic disease of horsegram at Bangalore is caused by Horsegram yellow mosaic virus whereas no PCR product was obtained from DNA extracted from healthy samples. It revealed that yellow mosaic disease of horsegram cultivated in and around Bangalore was caused by HgYMV.

The $1000 \mathrm{bp}$ PCR product was eluted from agarose gel and cloned into pTZ57R/T vector and transformed into competent E.coli cells (DH5 $\alpha$ strain). The recombinant clones containing $\mathrm{CP}$ gene were sequenced, assembled and its length was determined as $885 \mathrm{bp}$ including $111 \mathrm{bp}$ pre-coat protein at 5' end and 774 core coat protein. The length of the predicted amino acid sequence was found to be 257 .
Phylogenetic analysis, nucleotide sequence and amino acid sequence comparison of coat protein gene of yellow mosaic virus infecting horsegram

Phylogenetic tree based on full length coat protein gene sequences of HgYMV with 23 other geminivirus sequences downloaded from NCBI Genbank formed three major clusters of MYMIV, HgYMV and MYMV (Fig. 1). The present isolate formed unique cluster with HgYMV group that cause yellow mosaic disease symptoms in horsegram (AJ627904.1) and frenchbean (GU323321.1). The less horizontal spread of branches showed less sequence variation among these isolates. The branching out of different MYMIV and MYMV isolates suggested that these were entirely different viruses separated early in the evolution. From the above results, it is evident that yellow mosaic disease of horsegram in Bangalore is more closely related to other $\mathrm{HgYMV}$ isolates from different regions rather than MYMIV and MYMV.

Comparison of complete nucleotide sequence of coat protein gene of $\mathrm{HgYMV}$ with 23 other geminivirus sequences available in the NCBI Genbank (Table 2) indicated that coat protein gene of $\mathrm{HgYMV-GKVK-Bangalore} \mathrm{isolate}$ had maximum homology with HgYMVTamil Nadu:HG [AJ627904.1] (99.2\%), followed by HgYMV-Srilanka:FB [GU323321.1] (95.2\%). HgYMV-GKVKBangalore isolate had 85.2-86.9 per cent identity and 80.2-81.9 per cent identity with MYMV and MYMIV isolates, respectively. HgYMV-GKVK-Bangalore CP nucleotide sequence showed 86.9 per cent identity with MYMV: Combodia:MB [AY271892.1], followed by 86.8 per cent with MYMVMaharashtra:SB [AF314530.1] and 85.2 per cent with MYMV-Pakistan:SB [AY269991.1]. It had 8.19 per cent, 81.7 per cent and 80.2 per cent homology with 
MYMIV-India:SB [AY049772.1], MYMIVPakistan:MB [AY269992.1] and MYMIVAkola:MB [AY271893.1] isolates, respectively. From the above results, it is clear that HgYMV-GKVK-Bangalore is closely related to HgYMV-Tamil Nadu:HG and HgYMV-Srilanka:FB rather than MYMV and MYMIV. The full description of various isolates with their Genbank accession numbers used for sequence comparison were furnished in Table 8.

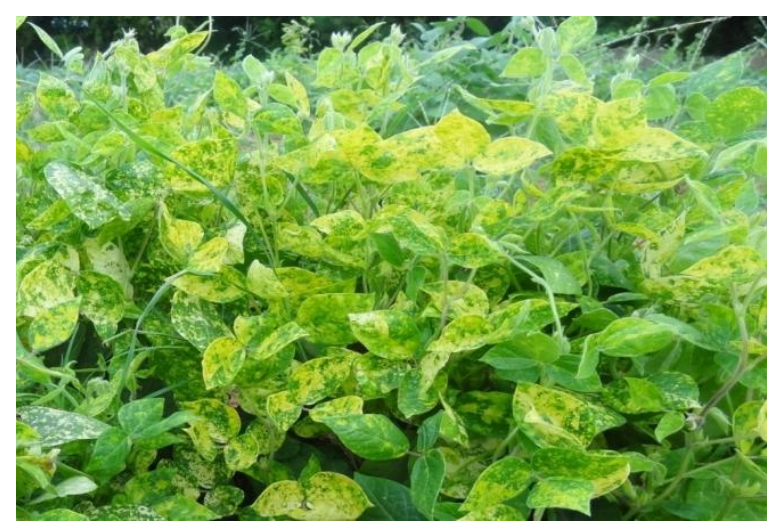

Plate.1 Horsegram plants showing typical symptoms of yellow mosaic virus

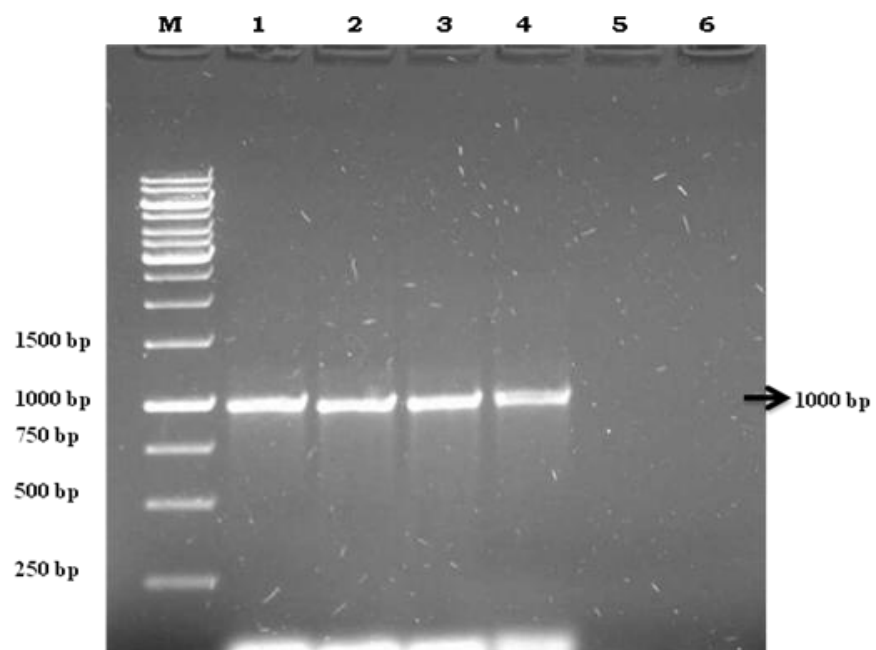

Plate.2 Amplification of coat protein gene of YMV infecting horsegram using HYMV-CPF/HYMV-CP-R primer pair

\section{Lane:}

M- $1 \mathrm{~Kb}$ Marker (Fermentas $1 \mathrm{~kb}$ DNA ruler)

Lane 1, 2, 3, 4 - Specific PCR product of 1000 bp from HgYMV infected sample

Lane 5 - Healthy horsegram plant DNA

Lane 6 - Water control 


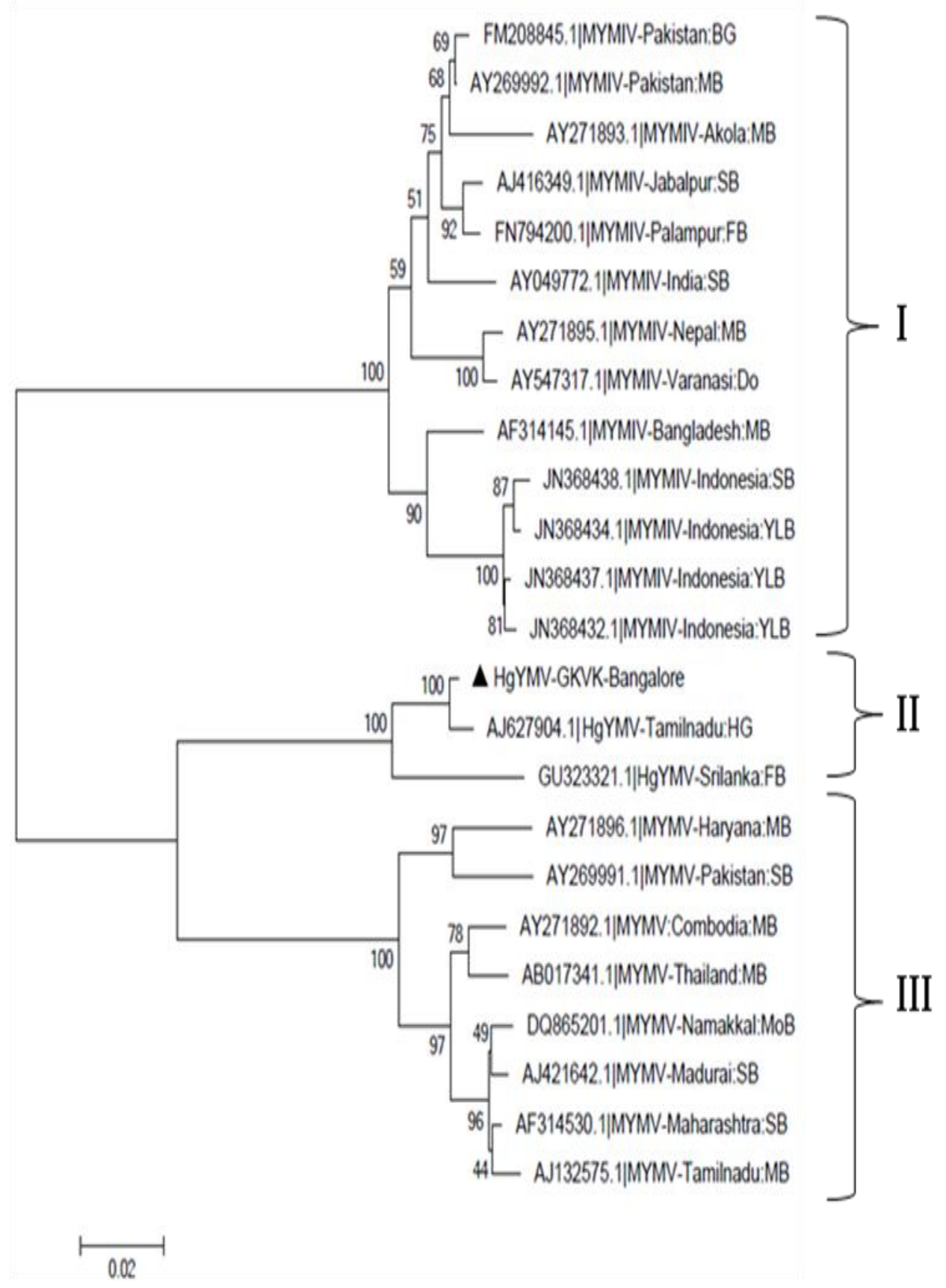

Figure.1 Phylogenetic tree obtained from comparison of complete nucleotide sequence of coat protein gene of $\mathrm{HgYMV}$ with other geminiviruses from database. The dendrograms are calculated using neighbor-joining algorithm of MEGA 5.1 version. Numbers at nodes indicate percentage bootstrap confidence scores (1,000 replications) 
Table.1 List of geminiviruses used for comparison of coat protein gene sequences, their origin, host species and NCBI accession numbers

\begin{tabular}{|c|c|c|c|c|c|}
\hline $\begin{array}{l}\text { Sl. } \\
\text { No. }\end{array}$ & Virus species & Abbreviation & $\begin{array}{l}\text { Geographical } \\
\text { origin }\end{array}$ & Host species & $\begin{array}{l}\text { Accession } \\
\text { number }\end{array}$ \\
\hline 1. & Horsegram yellow mosaic virus & HgYMV-Tamil Nadu:HG & Tamil Nadu & Horsegram (HG) & AJ627904.1 \\
\hline 2. & Horsegram yellow mosaic virus & HgYMV-Srilanka:FB & Srilanka & Frenchbean (FB) & GU323321.1 \\
\hline 3. & Mungbean yellow mosaic virus & MYMV-Haryana:MB & Haryana & Mungbean (MB) & AY271896.1 \\
\hline 4. & Mungbean yellow mosaic virus & MYMV-Namakkal:MoB & Namakkal & Mothbean (MoB) & DQ865201.1 \\
\hline 5. & Mungbean yellow mosaic virus & MYMV:Combodia:MB & Combodia & Mungbean (MB) & AY271892.1 \\
\hline 6. & Mungbean yellow mosaic virus & MYMV-Madurai:SB & Madurai & Soybean (SB) & AJ421642.1 \\
\hline 7. & Mungbean yellow mosaic virus & MYMV-Pakistan:SB & Pakistan & Soybean (SB) & AY269991.1 \\
\hline 8. & Mungbean yellow mosaic virus & MYMV-Maharashtra:SB & Maharashtra & Soybean (SB) & AF314530.1 \\
\hline 9. & Mungbean yellow mosaic virus & MYMV-Thailand:MB & Thailand & Mungbean (MB) & AB017341.1 \\
\hline 10. & Mungbean yellow mosaic virus & MYMV-Tamil Nadu:MB & Tamil Nadu & Mungbean (MB) & AJ132575.1 \\
\hline 11. & Mungbean yellow mosaic India virus & MYMIV-Indonesia:SB & Indonesia & Soybean (SB) & JN368438.1 \\
\hline 12. & Mungbean yellow mosaic India virus & MYMIV-Akola:MB & Akola & Mungbean (MB) & AY271893.1 \\
\hline 13. & Mungbean yellow mosaic India virus & MYMIV-India:SB & India & Soybean (SB) & AY049772.1 \\
\hline 14. & Mungbean yellow mosaic India virus & MYMIV-Indonesia:YLB & Indonesia & Yard long bean (YLB) & JN368437.1 \\
\hline 15. & Mungbean yellow mosaic India virus & MYMIV-Pakistan:BG & Pakistan & Blackgram (BG) & FM208845.1 \\
\hline 16. & Mungbean yellow mosaic India virus & MYMIV-Pakistan:MB & Pakistan & Mungbean (MB) & AY269992.1 \\
\hline 17. & Mungbean yellow mosaic India virus & MYMIV-Indonesia:YLB & Indonesia & Yard long bean (YLB) & JN368434.1 \\
\hline 18. & Mungbean yellow mosaic India virus & MYMIV-Indonesia:YLB & Indonesia & Yard long bean (YLB) & JN368432.1 \\
\hline 19. & Mungbean yellow mosaic India virus & MYMIV-Nepal:MB & Nepal & Mungbean (MB) & AY271895.1 \\
\hline 20. & Mungbean yellow mosaic India virus & MYMIV-Varanasi:Do & Varanasi & Fieldbean (Do) & AY547317.1 \\
\hline 21. & Mungbean yellow mosaic India virus & MYMIV-Bangladesh:MB & Bangladesh & Mungbean (MB) & AF314145.1 \\
\hline 22. & Mungbean yellow mosaic India virus & MYMIV-Jabalpur:SB & Jabalpur & Soybean (SB) & AJ416349.1 \\
\hline 23. & Mungbean yellow mosaic India virus & MYMIV-Palampur:FB & Palampur & Frenchbean (FB) & FN794200.1 \\
\hline
\end{tabular}


Table. 2 Nucleotide and amino acid sequence identities of coat protein gene of yellow mosaic virus infecting horsegram with other geminiviruses

\begin{tabular}{|c|c|c|c|c|}
\hline Sl. No. & Accession number & Sequences & Nucleotide sequence identity & Amino acid sequence identity \\
\hline 1. & AJ627904.1 & HgYMV-Tamilnadu:HG & 99.2 & 99.2 \\
\hline 2. & GU323321.1 & HgYMV-Srilanka:FB & 95.2 & 97.2 \\
\hline 3. & AY271896.1 & MYMV-Haryana:MB & 85.6 & 92.2 \\
\hline 4. & DQ865201.1 & MYMV-Namakkal:MoB & 86.4 & 91.4 \\
\hline 5. & AY271892.1 & MYMV-Combodia:MB & 86.9 & 91.8 \\
\hline 6. & AJ421642.1 & MYMV-Madurai:SB & 86.4 & 91.0 \\
\hline 7. & AY269991.1 & MYMV-Pakistan:SB & 85.2 & 91.4 \\
\hline 8. & AF314530.1 & MYMV-Maharashtra:SB & 86.8 & 91.8 \\
\hline 9. & $\mathrm{AB} 017341.1$ & MYMV-Thailand:MB & 86.5 & 91.0 \\
\hline 10. & AJ132575.1 & MYMV-Tamilnadu:MB & 86.4 & 91.8 \\
\hline 11. & JN368438.1 & MYMIV-Indonesia:SB & 80.7 & 83.6 \\
\hline 12. & AY271893.1 & MYMIV-Akola:MB & 80.2 & 83.2 \\
\hline 13. & AY049772.1 & MYMIV-India:SB & 81.9 & 84.4 \\
\hline 14. & JN368437.1 & MYMIV-Indonesia:YLB & 80.8 & 84.0 \\
\hline 15. & FM208845.1 & MYMIV-Pakistan:BG & 81.9 & 84.4 \\
\hline 16. & AY269992.1 & MYMIV-Pakistan:MB & 81.7 & 84.8 \\
\hline 17. & JN368434.1 & MYMIV-Indonesia:YLB & 80.7 & 83.2 \\
\hline 18. & JN368432.1 & MYMIV-Indonesia:YLB & 80.7 & 84.0 \\
\hline 19. & AY271895.1 & MYMIV-Nepal:MB & 80.7 & 84.0 \\
\hline 20. & AY547317.1 & MYMIV-Varanasi:Do & 80.8 & 84.4 \\
\hline 21. & AF314145.1 & MYMIV-Bangladesh:MB & 80.7 & 82.8 \\
\hline 22. & AJ416349.1 & MYMIV-Jabalpur:SB & 81.6 & 84.8 \\
\hline 23. & FN794200.1 & MYMIV-Palampur:FB & 81.3 & 84.8 \\
\hline
\end{tabular}


Comparison of predicted amino acid sequence of coat protein gene of $\mathrm{HgYMV}$ with 23 other geminivirus amino acid sequences available in the NCBI Genbank (Table 2) indicated that HgYMV-GKVK-Bangalore isolate shared maximum amino acid identity with $\mathrm{HgYMV}$ Tamil Nadu:HG [AJ627904.1] (99.2\%), followed by HgYMV-Srilanka:FB [GU323321.1] (97.2\%). HgYMV-GKVKBangalore isolate had 91-92.2 per cent identity and 82.8-84.8 per cent identity with MYMV and MYMIV isolates, respectively. It shared 92.2 per cent, 91.8 per cent, 91.8 per cent, 91.8 per cent and 91 per cent nucleotide identity with MYMV-Haryana:MB [AY271896.1], MYMV-Maharashtra:SB [AF314530.1], MYMV-Tamil Nadu:MB [AJ132575.1], MYMV:Combodia:MB [AY271892.1] and MYMV-Madurai:SB [AJ421642.1] isolates. It had 84.8 per cent, 84.8 per cent, 84.8 per cent and 82.8 per cent identity with MYMIV-Pakistan:MB [AY269992.1], MYMIV-Jabalpur:SB [AJ416349.1], MYMIV-Palampur:FB [FN794200.1] and MYMIV-Bangladesh:MB [AF314145.1]. From the above amino acid sequence alignment data, it is clear that HgYMV-GKVK-Bangalore isolate is more closely related to $\mathrm{HgYMV-Tamil} \mathrm{Nadu:HG}$ and HgYMV-Srilanka:FB rather than MYMV and MYMIV.

This was also validated during earlier investigations carried out by Naimuddin and Mohd. Akram (2010), Kamaal Naimuddin et al. (2011), Naimuddin et al. (2011), Obaiah (2011), Mohammad Nurul Islam et al. (2012), Naimuddin and Akram (2012), Prema and Rangaswamy (2018a), Prema and Rangaswamy (2018b), Prema and Rangaswamy (2018c) and Prema and Rangaswamy (2018d).

Coat protein genes have traditionally proven useful for plant virus identification and classification (Mayo and Pringle, 1998).
Because of its high degree of conservation, the coat protein ORF (CP or AV1) is the only begomovirus sequence approved by the International Committee on Taxonomy of Viruses for ascertaining the identity of a begomovirus (Mayo and Pringle, 1998), and the sequence comparison has been used to identify and classify geminiviruses (Padidam et al., 1995; Brown et al., 2001).

As per the latest guidelines if nucleotide identity at coat protein or complete DNA-A sequence is $>90 \%$, it will be considered as variant, strain or isolate of the same virus and $<90 \%$ will be considered as distinct species in begomovirus classification (Fauquet et al., 2008). The International Committee on Taxonomy of Viruses (ICTV) accepts the classification of begomoviruses based on $\mathrm{CP}$ gene sequences, when full length sequences are not available (Rybicki et al., 1998). Member of the genus Begomovirus are known to form clusters according to geographical origin with distinct branches for viruses from America, Africa and Asia. According to these guidelines, the yellow mosaic virus isolates from horsegram is a variant of horsegram yellow mosaic virus because of 99.2-95.2 per cent homology at nucleotide level.

Phylogenetic analysis based on coat protein gene sequences of $\mathrm{HgYMV}$ with 23 other geminivirus sequences formed three major subgroups consisting of of MYMIV, HgYMV and MYMV. HgYMV-GKVK-Bengalore isolate fell within the HgYMV subgroup and deviated from MYMV and MYMIV isolates indicating that virus specificity depends on host and geographical location. The present results from nucleotide and amino acid sequence comparison using $\mathrm{CP}$ gene sequences had clearly revealed that the yellow mosaic virus infecting horsegram was entirely distinct from yellow mosaic virus infecting greengram and blackgram. 


\section{Acknowledgements}

First author acknowledges Department of Science and Technology (DST), New Delhi for providing financial assistance for research through Inspire Fellowship.

\section{References}

Brown, J. K., Idris, A. M., Torres-Jerez, I., Banks, G. K. and Wyatt, S.D., 2001, The core region of coat protein gene is highly useful for establishing the provisional identification and classification of begomoviruses. Arch. Virol., 146: 15811598.

Fauquet, C. M. and Stanley, J., 2003, Geminivirus classification and nomenclature; progress and problems. Ann. Appl. Biol., 142: 165189.

Fauquet, C. M., Bisaro, D. M., Briddon, R. W., Brown, J. K., Harrison, B. D., Rybicki, E. P., Stenger, D. C. and Stanley, J., 2003, Revision of taxonomic criteria for species demarcation in the family Geminiviridae and an updated list of begomovirus species. Arch. Virol., 148: 405-421.

Fauquet, C. M., Briddon, R. W., Brown, J. K., Moriones, E., Stanley, J. and Zerbini, M., 2008, Geminivirus strain demarcation and nomenclature. Arch. Virol., 153: 783-821.

Francki, R. I. B., Hatta, T., Boccardo, G. and Randles, J. W., 1980, The composition of chloris striate mosaic virus, a geminivirus. Virology, 101: 233-241.

Harrison, B. D. and Robinson, D. J., 2002, Green shoots of geminivirology. Physiol. Mol. Pl. Pathol., 60: 215-218.

Harrison, B. D., Barker, H., Bock, K. R., Guthrie, E. J., Meredith, G. and Atkinson, M., 1977, Plant viruses with circular single-stranded DNA. Nature, 270: 760-762.

Jayan, P. K. and Maya, C. N., 2001, Studies on the germplasm collection of Horsegram (Macrotyloma uniflorum (Lam.) Verdc.). Indian J. Pl. Genetic Resources, 14: 43-47.

Kamaal Naimuddin, Mohammad Akram and Gupta Sanjeev, 2011, Identification of Mungbean yellow mosaic India virus infecting Vigna mungo var. silvestris L.
Phytopathol. Mediterr., 50: 94-100.

Mayo, M.A. and Pringle, C.R., 1998, Virus taxonomy-1997. J. Gen. Virol., 79: 649657.

Mohammad Nurul Islam, Sonia Khan Sony and Rita Sarah Borna, 2012, Molecular characterization of mungbean yellow mosaic disease and coat protein gene in mungbean varieties of Bangladesh. $\mathrm{Pl}$. Tissue Cult. Biotech., 22: 73- 81.

Muniyappa, V. and Reddy, H. R., 1976, Studies on the yellow mosaic disease of horsegram (Dolichos biflorus L.)- Virus vector relationships. Mysore J. Agric. Sci., 10: 605-610.

Muniyappa, V., Rajeshwari, R., Bharathan, N., Reddy, D.V.R. and Nolt, B.L., 1987, Isolation and characterisation of a geminivirus causing yellow mosaic disease of horsegram (Macrotyloma uniflorum) in India. J. Phytopathol., 119: 81-87.

Muniyappa, V., Reddy, H. R. and Shivashankar, G., 1975, Yellow mosaic disease of Dolichos biflorus L.(horsegram). Curr. Res., 4: 176.

Muniyappa, V., Reddy, H. R. and Shivashankar, G., 1976, Studies on the yellow mosaic disease on horsegram (Macrotyloma uniflorus Syn. Dolichos biflorus). III. Evaluation of germplasm for the disease. Curr. Res., 5: 52-53.

Naimuddin and Akram, M., 2012, Sequence comparison of coat protein gene of Mungbean yellow mosaic India virus isolates infecting mungbean and urdbean crops. J. Food Legume, 25: 286290.

Naimuddin and Mohd. Akram, 2010, Detection of mixed infection of begomoviruses in cowpea and their molecular characterization based on CP gene sequences. J. Food Legumes, 23: 191-195.

Naimuddin, Mohd. Akram, Aditya Pratap, Brijesh Kumar Chaubey and Joseph, K. John, 2011, PCR based identification of the virus causing yellow mosaic disease in wild Vigna accessions. J. Food Legumes, 24: 1417.

Nene, Y. L., 1972, A study of viral disease of pulse crops in Uttar Pradesh. Res Bull. No.4., G. B. Pant. Univ. Agri. Tech., 
Pantnagar, 144 pp.

Obaiah, S., 2011, Molecular detection and characterization of yellow mosaic virus infecting blackgram in Andhra Pradesh. $M$. Sc. (Agri.) Thesis, Acharya N.G. Ranga Agri. Univ., Hyderabad, 99pp.

Padidam, M., Roger, N. Beachy and Fauquet, C.M. 1995. Classification and identification of geminiviruses using sequence Comparisons. J. Gen. Virol., 76: 249-263.

Prema, G.U. and Rangaswamy, K.T., 2017, Field Evaluation of horsegram germplasm/ genotypes against horsegram yellow mosaic virus (HgYMV) disease and biological transmission of horse gram yellow mosaic virus to different leguminous hosts through white flies. Int. J. Agric. Sci., 9(54): 49344939.

Prema, G.U. and Rangaswamy, K.T., 2018a, Molecular detection and characterization of coat protein gene of mungbean yellow mosaic virus (MYMV) from Karnataka. Int. J. Agric. Sci., 10(3): 5118-5122.

Prema, G.U. and Rangaswamy, K.T., 2018b, Molecular detection and characterization of coat protein gene of soybean yellow mosaic virus from Karnataka. Ann. Agric. Res. New Series, 39(1): 72-79.

Prema, G.U. and Rangaswamy, K.T., 2018c, Molecular characterization of coat protein gene of blackgram yellow mosaic virus (BGYMV) from Karnataka, India. Int. J. Curr. Microbiol. App. Sci., 7(7): 22252235.

Prema, G.U. and Rangaswamy, K.T., 2018d, Molecular relationship and sequence comparison of coat protein gene of yellow mosaic virus isolates infecting different legume crops from Southern India. Ann. Agric. Res. New Series., 39(3): 290-300.

Prema, G.U., 2013, Molecular characterization of horsegram yellow mosaic virus and its management. Ph. D. Thesis, Univ. Agric. Sci., Bangalore, 271pp.

Qazi, J., Ilayas, M., Mansoor, S. and Briddon, R. W., 2007, Legume yellow mosaic viruses: genetically isolated begomoviruses. Mol. Pl. Pathol., 8: 343-348.

Rouhibakhsh, A., Priya, J., Periasamy, A., Haq, Q. M. I. and Malathi, V.G., 2008, An improved DNA isolation method and PCR protocol for efficient detection of multicomponents of begomovirus in legumes. J. Virol. Methods., 147: 37-42.

Rybicki, E.P. 1998. A proposal for naming geminiviruses: A reply by the Geminiviridae study group chair. Arch. Virol., 143: 421-424.

Sambrook, J. and Russel, D. W., 2001, Molecular cloning; A laboratory manual. 2nd edn., Cold Spring Harbour Laboratory Press, USA

Tamura, K., Dudley, J., Nei, M. and Kumar, S., 2007, MEGA4: Molecular Evolutionary Genetics Analysis (MEGA) software version 4.0. Mol. Biol. Evol., 24: 15961599.

Williams, F. J., Grewal, J. S. and Amin, K. S., 1968, Serious and new diseases of pulse crops in India in 1966. Plant Dis. Reptr., 52: 300-304.

\section{How to cite this article:}

Prema, G. U. and Rangaswamy, K. T. 2020. Molecular Characterization of Coat Protein Gene of Horse Gram Yellow Mosaic Virus (HgYMV) from Southern India. Int.J.Curr.Microbiol.App.Sci. 9(01): 1381-1391. doi: https://doi.org/10.20546/ijcmas.2020.901.152 